\title{
Detection of the origin of animal species in kebab meat using mitochondrial DNA based - Polymerase Chain Reaction (mtDNA-PCR)
}

\author{
K.I. Hassan*, B.A.M. Ali and N.A. Mohammed \\ College of Agricultural Sciences, Sulaimani University, Sulaymaniyah, Iraq \\ *email:_dr_kh2005_iraq@yahoo.com
}

(Received April 22, 2018; Accepted August 17, 2018)

\begin{abstract}
Adulteration and incorrect labeling of meat products became a matter of great concerns of religious, economical, legal and medical aspects. Among meat products, kebab is considered one of the most favorable in Iraq, which makes it prone to adulteration. This study was carried out to evaluate the quality of kebab by detecting the origin of animal species meat in it; using mitochondrial DNA (mtDNA) based Polymerase Chain Reaction (PCR) under laboratory conditions. For this purpose, kebab was prepared as per the standardized processing schedule using pure mutton and beef meat in ratio 80:20 and chicken meat in five ratios 70:20:10, 65:20:15, 60:20:20, 55:20:25 and 50:20:30, respectively. DNA was extracted successfully from pure species meat and from all mixed kebab above, then PCR was carried out using species-specific primers, to amplify mitochondrial cytochrome b (cyt b) gene. The results revealed specific amplified fragments with 133, 300 and 585 bp for pure chicken, beef and sheep, respectively, and in the mixed grilled samples, the detection limit of chicken was $10 \%$, indicating that the cooking (grinding) and addition of non-meat ingredients showed no effect on the detection of meat species. The results of this study proved mtDNA-PCR to be effective and reliable for detecting the origin of animal species meat. This method of detection could be applied in quality control laboratories for detect adulteration in different kinds of traditional grilled kebab in Iraqi restaurants.
\end{abstract}

Keywords: Kebab, animal origin, Detection, mtDNA, PCR

Available online at http://www.vetmedmosul.com

\section{الكثف عن نوع لحم الحيوان المستخدم في الكباب باستخدام تفاعلات تضاعف الانا المتسلسل المعتمد على دنا الميتوكونلدريا (mtDNA-PCR) خلود إبراهيم حسن، بانه أزاد محمد علي و ناسكه عبد القادر عمح كلية العلوم الزراعية، جامعة السليمانية، السليمانية، العراق}

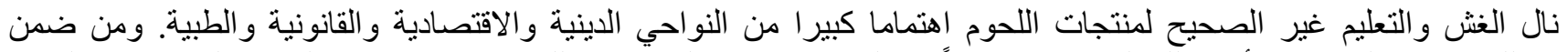

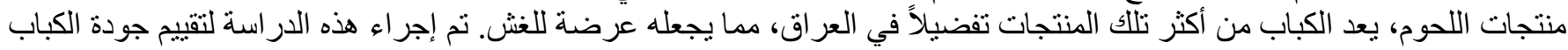

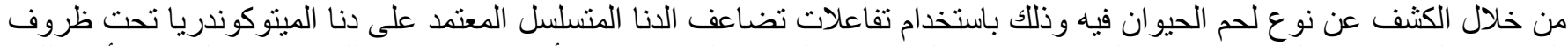

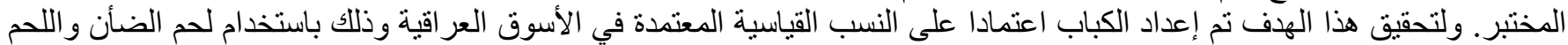

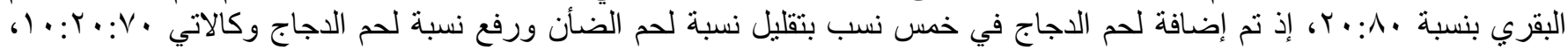

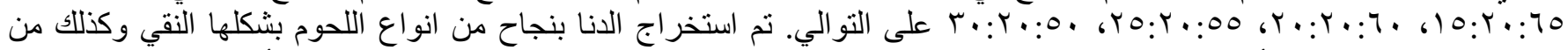

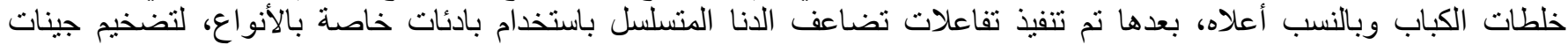

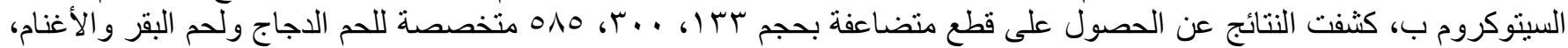

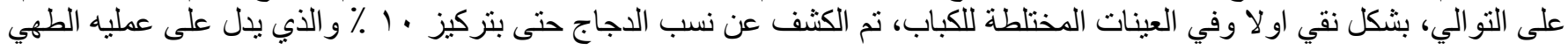




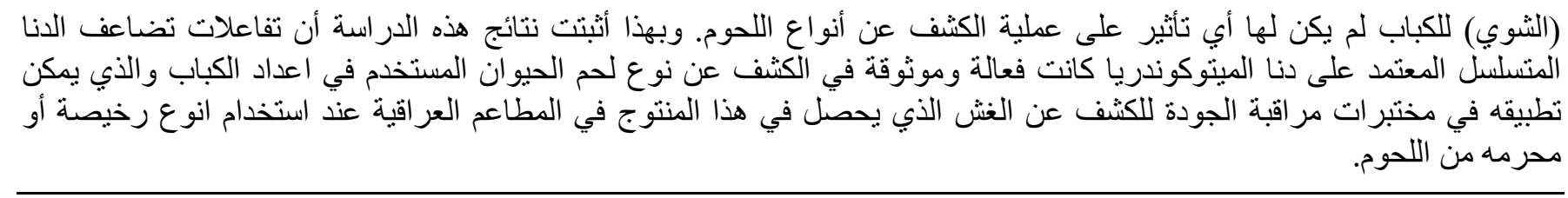

\section{Introduction}

The food industry provides the market with an increasing number and variety of raw, cooked and readyto-eat food products with different preparation methods using different food additives such as spices, salts and sugar. Meat products are considered to be a rich source of nutrients including protein, minerals, vitamins, poly unsaturated fatty acids, iron, zinc, and many micronutrients (1). The high demand on meat and meat products and their height cost makes them prone to adulteration. The act of intentionally substituting of one costly meat species with another cheaper one or using other meat species with false labels make it an important task for food control to be able to carry out species differentiation of the raw materials to be used for industrial food preparation and to detect animal species in food products (2). Meat species specification is an area which needs specialized attention in the food quality management system, it is a vital field to ensure the food safety to the consumers and it conserves the laws related to meat and meat products. The ability to detect objectionable species in meat products is important not only for economic, health, religious and ethical reasons, but also to ensure fair trade and compliance with legislation (3). Various methods have been applied for meat species specification; the physico-chemical methods gave idea about meat species based on the amount of certain chemicals present in meat of different animal species, but the reproducibility of these methods was not possible, and cannot be applied on processed meat and meat products (4), Furthermore the immunological techniques such as enzyme-linked immune sorbent assays (ELISA) were also used for meat species specification (5), but the available antisera shows cross reactions and were not effective on processing food, hence the immunological techniques face difficulty in distinguishing closely related species which hampers their effectiveness. Methods that based on protein analysis have also been applied for meat fraud identifications (6). The disadvantages of these methods are being time consuming, expensive and are not specific enough. Recently, DNA-based techniques, used for such purposes revealing high specificity, accuracy, reliability and legal acceptability, besides they are fast and inexpensive $(7,8)$. Moreover DNA are relatively stable at high temperatures, meaning that it can be analyzed not only in fresh and frozen food products, but also in processed, degraded and mixed commodities (9), hence, DNA based techniques are considered as the most appropriate methods for species detection and identification in processed foods (4). Among DNA based techniques Polymerase Chain Reaction (PCR) methods deserves special attention due to its high sensitivity and specificity as well as relatively short period of time necessary to perform the analysis. There are many types of PCR, which almost differ in the kind of primers they used. Specie Specific PCR means application of PCR on a species using specific primers that target sequence of DNA which are unique and specific to that species (10). It was used for identification of many animal species in meat products even in cooked meat under different processing conditions (11). The sequence of the DNA that have been targeting by PCR, may be nuclear DNA or mitochondrial DNA, both have been used, for identification of meat species. The target nuclear DNA's include: porcine leptin Gene (12), bovine beta-actin gene (13), whereas the target mitochondrial DNA's include: 12S rRNA (14), D-loop region (15) and cytochrome-b gene (16). The cytochrome $b$ gene of mtDNA was used to distinguish different types of meat like chicken, turkey, beef, pork, lamb, duck, goose, pheasant, quail and guinea fowl in meat products (17-20). In Iraq one of the most favorite meat products is kebab (21) which consists of mixed ground beef, mutton or goat meat with some of spice, salt, flour and chopped onion. Kebab is prone to adulteration using cheaper kinds of meat, hence the present study was carried out to evaluate the quality of kebab meat by detection of chicken meat using mitochondrial DNA based Polymerase chain reaction ((mtDNA-PCR) method.

\section{Materials and methods}

\section{Sampling}

Fresh lean beef (Bos taurus), sheep (Capra hircus) and chicken (Gallus gallus) were purchased from a local market in Sulaymaniyah - Iraq. The meat of each sample was minced separately to avoid cross contamination. The kebab was prepared according, to standard processing schedule using pure mutton and beef meat in ratio (80:20), then chicken meat was added in five ratios 70:20:10, 65:20:15, $60: 20: 20,55: 20: 25$ and 50:20:30 respectively. A total of $50 \mathrm{~g}$ of meat samples from individual species and $100 \mathrm{~g}$ of mixed meat samples were collected to make kebab. The samples so obtained were packaged in properly labeled LDPE bags. These mixtures were used as a reference material for DNA extraction. 


\section{DNA extraction}

The DNA was isolated from pure species and from the mixed meat using two methods (i) Kit (Gene aid, Korea) and (ii) phenol-choloroform-isoamil method (22) as follows: meat sample $(300 \mathrm{~g})$ was cut and homogenized using a knife and milled with mortar and pestle and liquid nitrogen. The homogenized sample was transferred into a sterile $15 \mathrm{ml}$ tube and $500 \mu \mathrm{l}$ of lysis buffer $(\mathrm{NaCl}, 50 \mathrm{mM}$; EDTA pH 8, $25 \mathrm{mM}$; Tris-HCl pH 7.6, $50 \mathrm{mM}$ ) and $20 \mu \mathrm{l}$ of proteinase $\mathrm{K}(10 \mathrm{mg} / \mathrm{ml}$ solution). The solution was incubated in a rotated stirrer at $56^{\circ} \mathrm{C}$ for $60 \mathrm{~min}$, then 500 $\mu \mathrm{l}$ of phenol: chloroform: isoamylalcohol $(25: 24: 1)$ was added to each microtube and mixed gently for $5 \mathrm{~min}$. The final suspension was centrifuged at $10000 \mathrm{x} \mathrm{g}$ for $5 \mathrm{~min}$. The aqua phase of each sample was carefully transferred to a new sterile $1.5 \mathrm{ml}$ microtube, and then $500 \mu \mathrm{l}$ chloroform was added to each sample. Centrifugation was repeated similar to the above conditions for $1 \mathrm{~min}$. The aqua's phase was transferred to a new sterile $1.5 \mathrm{ml}$ microtube. and $1 \mathrm{ml}$ of cold isoproponal with $50 \mu \mathrm{l}$ of $3 \mathrm{M}$ sodium acetate was added and the suspension was incubated on ice for $30 \mathrm{~min}$. Subsequently, the suspension was centrifuged at $10000 \mathrm{xg}$ for $10 \mathrm{~min}$ at $4{ }^{\circ} \mathrm{C}$. The supernatant containing alcohol was removed and the DNA pellet was washed with $250 \mu \mathrm{l}$ cold ethanol $(70 \%)$. The concentration and quality of the obtained DNA was determined by measuring the absorbance at $260 \mathrm{~nm}$. DNA quality (purity) was determined by measuring the absorbance at $260-280 \mathrm{~nm}$. The extracted DNA was stored at $-20{ }^{\circ} \mathrm{C}$ for further analysis.

\begin{abstract}
Amplification of cytochrome b gene
PCR amplification was performed using Master mix (Genet Bio, South Korea) containing a total volume of 12.5 $\mu 1$ reaction mixture (1U of Taq DNApolymerase, $10 \mathrm{mM}$ of Tris- $\mathrm{HCl}$ (pH9.0), $30 \mathrm{mM}$ of KCl, $1.5 \mathrm{mM} \mathrm{MgCl} 2,0.5 \mathrm{mM}$ each dNTPs (dATP, dCTP, dGTP, dTTP), $2 \mu$ l of DNA template (25-50ng) and $2 \mu \mathrm{l}$ primer (Genet Bio, Korea). Table 1 illustrated the information about the sequence of the primers used in this study. For DNA amplification, the following PCR program was used: One step of $2 \mathrm{~min}$ at 94 ${ }^{\circ} \mathrm{C} ; 30$ cycles, with one cycle consisting of 30 s at $94{ }^{\circ} \mathrm{C}, 60$ $\mathrm{s}$ at $60^{\circ} \mathrm{C}$ (for sheep and beef specific primers) $58{ }^{\circ} \mathrm{C}$ (for chicken primers), and $60 \mathrm{~s}$ at $72{ }^{\circ} \mathrm{C}$; and one step of $5 \mathrm{~min}$ at $72{ }^{\circ} \mathrm{C}$. The PCRs were performed with the thermo cycler (MWG Biotech, UK). In order to evaluate and verify the specificity of PCR protocol for each species, the primer pairs were tested by PCR on DNA templates prepared form other kinds of species. The products of PCR reaction were run on $1.2 \%$ agarose gel electrophoresis and stained by ethidium bromide to visualize the amplified fragments under UV.
\end{abstract}

Table 1: The sequence of primers for each type of animal studied with the molecular size of the expected amplified product

\begin{tabular}{lccc}
\hline Species & Primer Sequences (5'-3') & Expected size (bp) & Reference \\
\hline Sheep & Forward: TAC CAA CCT CCT TTC AGC AAT T & 585 & Zarringhabaie et al. (23) \\
Chicken & $\begin{array}{c}\text { Reverse: TGT CCT CCA ATT CAT GTG AGT GT } \\
\text { Forward: AGC AAT TCC CTA CAT TGG ACA CA }\end{array}$ & 133 & Bo et al. (24) \\
Beef & $\begin{array}{c}\text { Forward: GAT GAT AGT AAT ACC TGC GAT TGC } \\
\text { Reverse: CGT GAT CTA ATG GTA AGG AAT A }\end{array}$ & 300 & Kotowicz et al. (25) \\
\hline
\end{tabular}

\section{Results and discussion}

In order to evaluate and verify the specificity of the species-specific primers in this study, each pair of primers was performed at first in PCR reaction using the DNA extracted from the meat of pure individual species (chicken, beef and sheep). The reaction generated specific fragments, as the electrophoresis indicated single specific band with the expected size of 133, 300 and 585 bp for chicken, beef and sheep respectively, and no fragment, was produced by non-specific amplification. To evaluate the specificity of the chicken primers, the PCR was carried out on the DNA extracted from the kebab mixed samples (Figure 1) and results expected an amplified product (133 bp) for all mixtures that contain chicken, with different concentration even in the ratio of $10 \%$. However, more intense bands were seen as the rate of chicken meat was increased (Lane 5 and 6 in figure 1). The chicken specific primer was used for the detection of chicken meat among other meat products by Kitpipit et al. (26), Bo et al. (24). The successful detection of this target fragment using PCR may be due to the small size of amplicon (133bp). Previous reports have also shown that amplicon size of less than $150 \mathrm{bp}$ has a higher chance of survival in cooked samples (15), as the cooking causes extensive changes in the meat tissue during heat treatment which make the speciation becomes difficult in cooked samples.

PCR amplification using beef specific primer (Figure 2) produce amplified product with $300 \mathrm{bpp}$ and with approximately the same intense bands for all of mixtures, due to the equal ratio of beef meat $(\% 20)$ in all of the mixtures. Beef specific primer was also used by Mehdizadeh et al. (27) and Kotowicz et al. (25) for the detection of beef meat using PCR techniques. In application 
of PCR using the sheep specific primers (Figure 3), amplified product with the expected size $(585 \mathrm{bp})$ produced in all the mixtures with a decrease in the intensity of the bands due to the decrease in the concentration of sheep meat from $70 \%$ to $30 \%$, sheep specific primers were also used by Zarringhabaie et al. (23) and also by Bhat et al. (28) for detection of sheep meat in processed food using PCR.

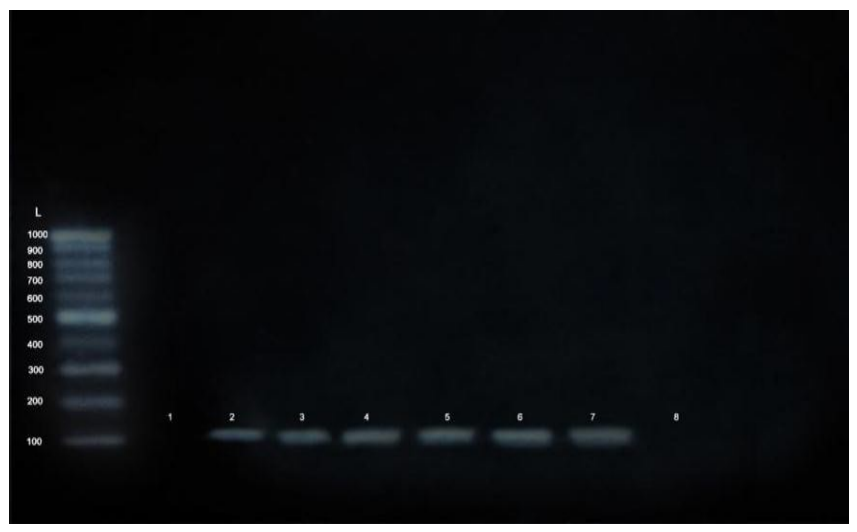

Figure.1: PCR product with $133 \mathrm{bp}$ using chicken specific primer in 1.2\% agarose gel electrophoresis. lane 1 represent DNA ladder, lane1 have no chicken meat, lane $2 ; 10 \%$ chicken meat, lane 3: 15\% chicken meat, lane 4; $20 \%$ chicken meat, lane $5 ; 25 \%$ chicken meat, lane $6 ; 30 \%$ chicken meat, lane 7; positive control and lane 8; Negative control.

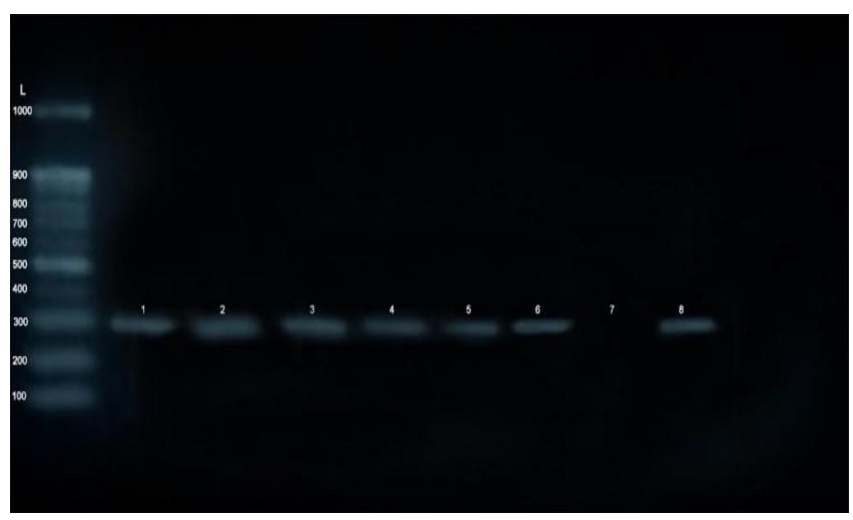

Figure.2: PCR product with 300 bp using Beef specific primer in $1.2 \%$ agarose gel electrophoresis, lane L; DNA ladder, lane (1-6) contain $20 \%$ of beef meat, lane 7; negative control and lane 8; positive control.

Consequently, the Mitochondrial DNA (mtDNA) based PCR procedure used in this study proved to be effective and reliable in detecting the animal origin of kebab meat. The reason for using mitochondrial DNA for the detection of animal species in any meat product is due to its high copy number which give high chances for their survival and less chances of degradation under different meat processing conditions thereby making it ideal for meat species identification in processed samples $(29,30)$. This assay has many other applications in identification of fraud meat and meat products, such as the detection of foreign or undesired or forbidden animal species in commercial meat products. It is suggested that this method of detection can be applied to quality control to detect the adulteration in different types of meat and meat products. The species-specific primer technique employed here is better than barcoding because it is much faster and the sequence data from cyt $b$ genes are available on DNA databases for many species and cheaper. However, this assay has its limitations in that it cannot provide quantitative data, unlike real-time PCR (12), Thus, quantitative real-time PCR technique to quantify the presence of animal material in foodstuff samples was suggested especially for the identification of small amounts of DNA.

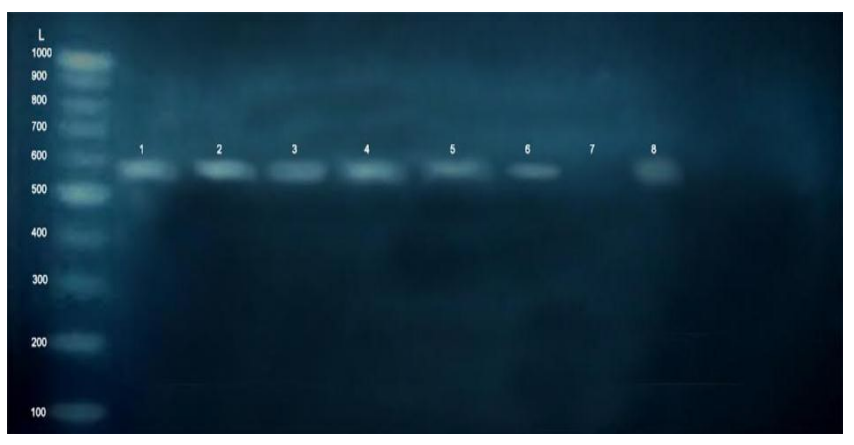

Figure 3: PCR product with 585 bp using sheep specific primer in $1.2 \%$ agarose gel electrophoresis, lane L; DNA ladder, lane 1; mixture contain $75 \%$ sheep meat, lane 2 : $70 \%$ sheep meat, lane 3: $65 \%$ sheep meat, lane 4: $60 \%$ sheep meat, lane 5: 55\% sheep meat, lane 6: $50 \%$ sheep meat, lane 7 and 8 were Negative and positive controls, respectively.

\section{Conclusions}

It was concluded that mitochondrial DNA (mtDNA) based PCR procedure used in this study proved to be effective and reliable in detecting the animal origin in kebab to level of $10 \%$ and that the processing cooking (grinding) and addition of non-meat ingredients showed no hindrance in the detection of meat species.

\section{References}

1. Biesalski HK. Meat as a component of a healthy diet - are there any risks or benefits if meat is avoided in the diet. Meat Sci. 2005;70:509524. 
2. Aida AA, Che Man YB, Wong CMVL, Raha AR, Son R. Analysis of raw meats and fats of pigs using polymerase chain reaction for Halal authentication. Meat Sci. 2005;69:47-52.

3. Nakyinsige K, Che YM, Sazili A, Halal authenticity issues in meat and meat products. Meat Sci. 2012;91(3):207-214

4. Singh VP, Sachan N. Meat species specifications to ensure the quality of meat: a review. Int J Meat Sci. 2011;1:15-26.

5. Chen FC, Hsieh YHP. Detection of pork in heat processed meat products by monoclonal antibody-based ELISA. J AOAC Int. 2000;83(1):79-85.

6. Skarpeid HJ, Kvaal K, Hildrum KI. Identification of animal species in ground meat mixtures by multivariate analysis of isoelectric focusing protein profiles. Electrophoresis. 1998;19(18):3103-3109.

7. Hong-yang W, Jia-qin L, Jia-qi W, Deng-pan B, Dan L, Li W, Lingyun Z. Development and application of a PCR approach for detection of bovis, sheep, pig, and chicken derived materials in feedstuff. Agri Sci China. 2008;7:1260-1266.

8. Yin R, Bai W, Wang J, Wu C, Dou Q, Yin R, He J, Luo G. Development of an assay for rapid identification of meat from yak and cattle using polymerase chain reaction technique. Meat Sci. 2009;83:38-44.

9. Lenstra J. DNA Methods for identifying plant and animal species in food. In Lees M. editor. Food authenticity and traceability. Florida: CRC Press; 2003. p. 34-36.

10. Rojas M, Gonzalez I, Fajardos V, Martın I, Herna PE, Garcı AT. Authentication of meats from quail (Coturnix coturnix), Pheasant (Phasianus colchicus), Partridge (Alectoris spp), and Guinea Fowl (Numida meleagris) Using Polymerase chain Reaction Targeting Specific Sequences from the mitochondria 112s rRNA Gene. Food Con. 2009;20(10):896-902.

11. Mane BG, Mendiratta SK, Tiwari AK. Polymerase Chain Reaction Assay for identification of chicken in meat and meat products. Food Chem. 2009;116(3):806-810.

12. Koppel R, Ruf J, Rentsch J. Multiplex real-time PCR for the detection and quantification of DNA from beef, pork, horse and sheep. Eur Food Res Technol. 2010;232(1):151-155.

13. Koppel R, Ruf J, Zimmerli F, Breitenmoser A. Multiplex real-time PCR for the detection and quantification of DNA from beef, pork, chicken and turkey. Eur Food Res Technol. 2008;227(4):1199-1203.

14. Fajardo V, Gonzalez I, Rojas M, Garcia T, Martin R. A review of current PCR-based methodologies for the authentication of meats from game animal species. Tren Food Sci Technol. 2010;21(8):408421.

15. Ali M, Hashim U, Mustafa S, CheMan Y, Yusop M, Bariet M. Nanoparticle sensor for label free detection of swine DNA in mixed biological samples. Nanotechnol. 2011;22:195-503.

16. Jain S, Brahmbhait MN, Rank DN, Joshi CG, Solank JV. Use of cytochrome $\mathrm{b}$ gene variability in detecting meat species by multiplex PCR assay. Indian J Anim Sci. 2007;77:880-881.
17. Hird H, Goodier R, Hill M. Rapid detection of chicken and turkey in heated meat products using the polymerase chain reaction followed by amplicon visualization with vistra green. Meat Sci. 2003;65:11171123.

18. Dooley JJ, Paine KE, Garrett SD, Brown HM. Detection of meat species using TaqMan real-time PCR assays. Meat Sci. 2004;8:431438.

19. Hird H, Chisholm J, Brown J. The detection of commercial duck species in food using a single probe-multiple species specific primer real-time PCR assay. Eur Food Res Technol. 2005;221(3):559-563.

20. Schwägele F, Stirtzel S, Andree S. Authentication of domestic poultry species in meat and meat products. Proceedings of the $53^{\text {rd }}$ International Congress on Meat Science and Technology, Beijing, China. 2007;617-618.

21. Kayisoglu S, Yilmaz I, Demirci M, Yetim H. Chemical composition and microbiological quality of the doner kebabs sold in Tekirdag market. Food Cont. 2003;14:496.

22. Sambrook J, Russell DW. Purification of nucleic acids by extraction with phenol: Chloroform. Cold Spring Harbor Prot. 2006; doi: $10.1101 /$ pdb. prot 4455 .

23. Zarringhabaie G, Pirany N, Javanmard A. Molecular traceability of the species origin of meats using multiplex PCR. African J Biotechnol. 2011;10:461-465.

24. Bo H,Xianrong M, Liyuan $\mathrm{Z}$, Jinyue $\mathrm{G}$ Shaowen $\mathrm{L}, \mathrm{Hu} \mathrm{J}$. Development of a sensitive and specific multiplex PCR method for the simultaneous detection of chicken, duck and goose DNA in meat products. Meat Sci. 2015;101:90-94.

25. Kotowicz M, Adamczyk E, Bania J. Application of a duplex-PCR for detection of cows' milk in goats' milk. Ann Agri Environ Med. 2007;14:215-218.

26. Kitpipit T, Sittichan K, Thanakiatkrai, P. Direct-multiplex PCR assay for meat species identification in food products. Food Chem. 2014;163:77-82

27. Mehdizadeh M, Mousavi SM, Rabiei M, Moradian K, Eskandari S, Abbasi Fesarani M, Rastegar H, Alebouyeh M. Detection of chicken meat adulteration in raw hamburger using polymerase chain reaction. J Food Qual Haz Cont. 2014;1(1):36-40.

28. Bhat M, Salahuddin M, Mantoo AI, Sheikh Adil, Henna J, Ashraf M. Species-specific identification of adulteration in cooked mutton Rista (a Kashmiri Wazwan cuisine product) with beef and buffalo meat through multiplex polymerase chain reaction. Vet Worl. 2016;9(3):226-230.

29. Partis L, Croan D, Guo Z, Clark R, Coldham T, Murby J. Evaluation of a DNA fingerprinting method for determining the species origin of meats. Meat Sci. 2000;54:369-376.

30. Rudi K, Hoidal HK, Katla T, Johanen BK, Nordal J, Jakobsen K. Direct real-time PCR quantification of Campylobacter jejuni in chicken fecal and cecal samples by integrated cell concentration and DNA purification. Appl Environ Microbiol. 2004;70:790-797. 